\title{
Investigating the Impact of Facebook on Consumer Attitude ${ }^{1}$
}

\author{
BI BI Aisha Amin ${ }^{2}$ \\ Burçin Kaplan ${ }^{3}$
}

\begin{abstract}
The way a consumer thinks about a particular brand is one of the most significant aspects in making purchase decisions. Nowadays organizations aim to make their products memorable and create points of difference in their products or strategies. In this study the perception regarding the brand pages and their attitude towards Facebook advertisement are focused. An online questionnaire was published. The respondents to the questionnaire were all active Facebook users in Turkey. In this study among different types of social media sites Facebook is considered, there are facilities provided through Facebook that usually brands use them such as fan pages, advertising. The findings based on the analyses suggest that there are no significant differences between gender considering perception towards the brand pages and no differences regarding consumer attitude towards Facebook advertisements furthermore the perception of a brand page does affect consumer attitude towards advertisements. This study concludes that building a brand requires providing or enhancing online brand pages, moreover, creating the most relevant ads and creating interaction with consumers. There are vital strategies of building brand such as online presence, communicating and using social networking sites as a platform to reach the target audience.
\end{abstract}

Keywords: Marketing, Advertising, Social media, Consumer Attitude, Brand Perception.

\footnotetext{
${ }^{1}$ This study is a part of unpublished master's thesis "Investigating the Brand Facebook Pages for Brand Perception and Consumer Attitude in Turkey".

2 Istanbul Aydin University, Department of Business Management, bibiamin@stu.aydin.edu.tr, orcid.org/0000-0002-2891-5283.

3 Dr., Istanbul Aydin University, Department of Business Management, burcinkaplan@aydin.edu.tr, orcid.org/0000-0003-4967-8405.

*Received: 20.01.2021, Accepted: 05.03.2021.

DOI: 10.17932/IAU.FCPE.2015.010/fcpe_v07i1004
} 


\section{INTRODUCTION}

Social media sites have gained more attention of marketers. When a Facebook page is designed and the advertisements are prepared the main goal is to gain the consumer attention and affect their attitude toward the brand, consequently this process affects purchase intentions. (LongCrowell, 2020). Brand perception is about the thoughts that consumers have regarding brands and the organization culture (Coleman, 2019). Essentially the nature of this study is descriptive, presumed to define the effect of perception about brands' Facebook page on the consumer attitude toward brand Facebook advertisement moreover, gender is considered as a factor. This research aims to provide a more general and deep view on consumer attitude toward advertisement strategies used in social media. The basic point is related to building permanent relationship with consumers, moreover, investigating the procedures to be in their minds and increase brand awareness.

\section{Objectives}

1- Measuring the effect of gender on consumer attitude toward Facebook ads and brand perception.

2- Measuring the relationship between brand perception and consumer attitude.

\section{Research Questions}

Is there any difference in perception about the brand's Facebook page according to gender?

Is there any difference in consumer attitude toward the brand's Facebook advertisement according to gender?

Is there any significant impact of perception about the brand's Facebook page on consumer attitude toward brand's Facebook advertisement?

\section{LITERATURE REVIEW}

Nowadays creating a relevant content in the social media sites is considered as a point of parity, it makes the brand recognizable but it's up to the brand managers to create their point of difference among their rivals. The effects that are created or reinforced by the social media in attitude and perception of consumers are the backbone of the consumer-brand 
relationship. Social media is gaining more popularity, it has enhanced communication platforms. A study claims that social media enhances as the time passes and develops mobility, the "user fatigue" and skills needed to use the social media sites are two mains in an exploratory quantitative research, the consumer attitude toward Facebook ads and posts were getting compared, the result indicates that consumer attitude toward posts were more positive than ads, consumers were annoyed by ads (Ferreira $\&$ Barbosa, 2017: 45)

Knowing the "target audience" replying to their important questions, knowing their journey, exploring the things that inspire them is the rule of success for marketers. The secret of raising value is providing value for the "target audience" (Frey, 2016).

\section{Social Media}

Social media reinforces the interest of "potential consumers" and provides them the platform to learn about the products and services moreover, it makes the interactivity of "supply" and "demand" easier (Madsen \& Slåtten, 2015: 11). Based on this type of use, businesses have a huge amount of data, from the number of sales, the number of products examined, from the comments made on the products to the brand evaluations made on social networks. There, it can be said that the most important output of the analysis of this big data contributes the development of marketing strategies in social media for these companies (Gülpınar Demirci \& Kaplan, 2020). Effective usage of social media with the right strategies has an increasing effect on the profitability of businesses. The Social media usage is popular among people and is accepted as a communication platform, it's being used by marketers although some organizations don't allow their employees to use social media some organizations allow social media usage depending on their strategies (Archambault \& Grudin, 2012).

Social media reinforces the interest of "potential consumers" and provides them the platform to Know. There are allegations that social media increases business returns meanwhile it is difficult to know the science of affection on consumer-brand relationships and returns on investments (Dutot \& Mosconi, 2016). When the social media is used along with the business intelligence, this combination makes the reach of target consumers more effective and efficient. Moreover, advertising gets more 
efficient. Associating "social media" with "business intelligence" brings effectiveness and efficiency to their targeting strategies and advertising strategies (Divol et al., 2012 as cited in Dutot \& Mosconi, 2016: 1). Social media is a great opportunity to establish significant relationships and create ways of social interaction defined through dynamic exchanges between their members.

\section{Facebook as Social Networking Site}

Information is the most important aspect of life. However the efficiency and accessibility to receive the correct information are essential. Social media makes the communication process easier and helps to create social relationships when Facebook was created by Zuckerberg in 2005, it became one of the speediest components of the Web 2.0 environment. A "cross-national" information affirms that there were $51 \%$ of their survey respondents who prefer social media as a source of news. Moreover, according to the allegations Facebook was mentioned as popular staging for daily news (Newman et al., 2016 as cited in Welbers \& Opgenhaffen, 2019). The reason behind establishing communication among "marketers" and members of brand community is transferring information to the "marketers" and providing them the valuable details to apply the needed improvements (Ramle \& Kaplan, 2019).

Companies have aligned their business model with Facebook as in 2018 Facebook hosted 90 million companies and was used by 6 million advertisers. Facebook collects demographic information of 2.2 million active users moreover these all statistics describe Facebook as almost free and connective media (Van Dijck, 2013 as cited in Helmond et al., 2019: 123).

Past purchases can cause the buyer to repeat their purchases furthermore building trust and being present on social media works as "mediator" (Weisberg et al., 2011). In a research done in the U. S. regarding social networking sites and purchase intension, it was claimed that there is a positive relationship between the impact of posts that were shared by friends on purchase intension. $81 \%$ who faced their friends' posts regarding special brand those posts affected their purchase intension (Olsenki, 2012)

Facebook has developed new trends which are changing and enhancing the 
platform such as creating "group-centric" design, there are some facilities of this "redesign" like enhancing the access for exploring other "groups" also the related "updates" will be displayed on "news feed" (Sehl, 2020)

There are around $67 \%$ of "social advertisers" who suggest that Facebook is the most effectual "social media site", there are 7 million advertisers on Facebook and the average "cost-per-click" on Facebook is $\$ 1.72$, the potential reach of advertising for Facebook is 1.9 billion" (Siu, 2020)

Brands are more than just tags it's more about creating a relationship with "consumers" and keeping them loyal to your brand, "social media" have been used for around 40 years although Facebook created the platform for marketing and by doing so the attentions of "marketers" where obtained (Chen, 2020). "Facebook, on the other hand, is a platform intended for networking and connecting with friends. It is for people connecting with people you know.

\section{Consumer Attitude}

Studies claim that attitude is learned and if attitude related to "purchase decision" is learned then there are several incentives that reinforce the learning process such as "experience" from products or services, advertising, customer service, information earned from people and "mass media" (Asiegbu et al., 2012: 40). Muheling in (1987) claimed that "consumer attitude toward advertisement" involves several dimensions and covers "attitude toward" the "instruments" used by "advertisers" moreover, "consumer perception" is one the most important factors however "consumer perception" is affected by economic and social conditions (Kwon, 2005: 18)

People with "social escapism" incentives like ads on "web advertising"; they enjoy it because they are getting entertained moreover, people with "high internet ability" have positive attitude toward "web advertising" because of the information access, those people who are keen to get the information, they prefer social media ads because of "informativeness" and perceived entertainment perspectives (Zhou, 2002).

Findings of a study about "millennials ' attitude toward food- truck dining" argues that "hygienic", "convenience", "hedonic" factors and "environmental risks" effect consumer attitude toward "food-truck 
dining"; "hedonic" elements are supportive whereas "hygienic", "convenience" and "environmental risks" have a negative impact on consumer attitude toward "food- trucks dining" (Yoon \&Chung, 2017: 1)

Attitude is composed of knowledge, feelings and actions and there is consistency between the three aspect of attitude (Madichie, 2012). The cognitive component of consumer attitude indicates "knowledge" and opinions toward an object moreover, it relates to information gathered from different sources and the direct experience of consumers Affective: Illustrates "emotions" and "feelings" (Noel. 2020).

The affective aspect of attitude indicates emotions for example, someone loves flowers for any reason whereas behavior shows the way people act with regards to an object, for example watering flowers. (Iedunote, 2017). All of the three elements of consumer attitude are "consistent" with each other if one of them changes the other changes in one part can convince the other two parts to change (Hawkins et al, 2001 as cited in Asiegbu et al., 2012b: 45). Attitudes indicate opinion and ideas, overall attitude could be both "positive" and "negative" in some situations attitude could be uncertain for instance, sometimes we have different emotions toward a particular object (Kakri, 2019).

\section{Brand Perception}

Perception indicates the process where motives can be perceived by "organism" and turned to reasonable "experience" toward an object. Moreover, perception is linked with attitude (Lindsay \& Norman, 1977 as cited in Picken, 2005: 52). The brand perception is an important concept in marketing and must be considered during brand tracking process moreover, brand perception provokes "buying behavior" and have a massive impact on marketing strategies (Romaniuk \& Sharp, 2002). Perception is related to thoughts and views, attitude is the reflection of thoughts in behaviors for example, people might dislike something by talking or complaining but their perception about that related object is created previously (Tauber, 2014).

The process of building brands does not concentrate on only "tangible" aspects of brands because that could be easily "copied", the most important part is making the connection of consumer with the brand stronger. There are images related to the brand in consumers ' minds which could create a 
different picture of brands, for marketers, it's necessary to be aware of these pictures (Tuskej, 2010). Brand perception is the most important aspect of "brand equity", knowing the impact of social media is necessary in order to enhance the perception of consumers about a brand (Helbling, 2018). In a study done by Kaplan in Turkey, consumer perception`s impact on consumer loyalty was examined, the findings claim that there are factors influencing "customer loyalty" such as customer perception about quality of service, consumer perception about product, "comparative price perceptions", "discount perceptions", "value perceptions", and "customer satisfaction" (Kaplan, 2015).

Nowadays information is shared easily which impacts the brand perception of consumers, meanly brand perception indicates the idea of the consumers about your brand it's completely owned by consumers. There are "surveys" and "focus groups" used to extract brand perception. Characteristics of consumers and their location can also impact their brand perception (Smith, 2015). Brand perception is important because when it's positive it makes the brand selected among its rivals, moreover $60 \%$ of satisfied customers will suggest the brand to their peers. Brand perception could be extracted from platforms created by internet such as "google alert", "online reviews", "social media" and different types of surveys (Barrett, 2020).

Consumers are keen to know about "products" and services of "brands" and this function "need to Know" increases the possibility of brand positioning and that's the reason of designing the strategies which affect the knowledge of consumer about products of brands (D'Souza, 2008). Regarding online trust, it was found that the great amount of "e-commerce knowledge", "perceived risk" and "perceived trust" have their impact on "online trust" (WR, 2015). There are differences in consumer behavior regarding "gender identity", from developing a perception, forming attitude, and behaving in a particular manner gender identity affects these processes (Bem, 1981 as cited in Ye \& Robertson, 2012: 83).

Studies claim that there are differences between women and men recognizability regarding objects as the Vanderbilt psychologists argue that women are good in recognizing "living thing" than men and men are better in "vehicle recognizing" (Nauert, 2012). There is evidence that shows the difference between the attitude of men and women in social 
media. Men prefer "formal speech" than women. In "interactions" women's behavior is warmer than men (Atanasova, 2016). There are differences in women and men perceptions, as studies claim that women are able to catch the small details because of the extra amount of "rods and cones" in their eyes moreover, women relate their feelings with the object, for example, if women go out for shopping, they want to feel it on the other hand men see shopping as a goal (Patterson, 2017).

The effect of gender is "endemic" to all kinds of social media such as "Facebook", Instagram, Blogs and "online games" (Webb \& Temple, 2015). Women use social media to share personal information than men, on the other hand, men use social media for business reasons (Vermeren, 2015). Gender has a significant impact on attitude toward brand image and purchasing minimal marketing products (Haron, 2015).

\section{CONCEPTUAL FRAMEWORK}

$\mathrm{H}_{1}$ : Hypothesis:

$\mathrm{H}_{1}$ : There are differences between the perception of women and men regarding the brands` Facebook pages.

$\mathrm{H}_{0}$ : There are no differences between the perception of women and men regarding the brands` Facebook pages.

$\mathrm{H}_{2}$ Hypothesis:

$\mathrm{H}_{1}$ : There are differences between women and men consumer attitude toward the brands` Facebook advertisements

$\mathrm{H}_{0}$ : There are no differences between women and men consumer attitude toward the brand's Facebook advertainments

$\mathrm{H}_{3}$ Hypothesis:

$\mathrm{H}_{1}$ : There is a significant impact of perception about the brands ' Facebook pages on consumer attitudes toward brands ` Facebook advertisements.

$\mathrm{H}_{0}$ : There is no significant impact of perception about the brands' Facebook page on Consumer attitude toward brands' Facebook advertisements.

This research is studying the relation between perception about brands Facebook page as an independent variable and consumer attitude toward 
brands' Facebook advertisement as a dependent variable comparing between females' and males' attitudes. The method used for this study is a quantitative method.

For this study, the data were collected via a questionnaire provided electronically to the respondents, which will result in further information being obtained. Participants of the questioner replied to the two main parts of queries, the part of demographics data and the part of the study hypotheses variable queries, before answering the questions the participants were asked to imagine their favorite brands ' Facebook pages. The survey was accepted by the ethical committee of Istanbul Aydin University.

\section{RESEARCH DESIGN AND SET UP}

\section{Population and Sampling}

The target population was Facebook users in Istanbul - Turkey, concentrating on youth. The researcher targeted students of universities to study the attitude of the young generation. In this study a convenience sampling method was used to select the target respondents. (Through a message the respondent were asked to think of their favorite Facebook brand page while answering the questions). After removing the unengaged respondents, the total responses are 227 responses which are divided almost half and half between females and males as $58 \%$ of the responses are from males and $42 \%$ are from females.

Table 1: The Sample Size

\begin{tabular}{ccc}
\hline \hline Position & Frequency & Percent \\
\hline Males & 131 & $58 \%$ \\
Females & 96 & $42 \%$ \\
\hline Total & $\mathbf{2 2 7}$ & $\mathbf{1 0 0 . 0}$ \\
\hline
\end{tabular}




\section{Data Collecting Tool}

The Data collection process was practiced through survey and the questions were borrowed from two studies as one of studies was written by Ana Margarida Barreto (2013) and the second part of the questions were borrowed from Xueying Zhang (2013). Survey was distributed through Facebook, Messenger and WhatsApp. Survey is composed of 28 questions and it was made with the help of Survey Planet application there were multiple choice questions and Likert scale used meanwhile respondent could select five items in order to respond Likert questions such as (Strongly disagree, Disagree, Neither, Agree, Strongly Agree). Responses were accepted only from Facebook active users. The questioner starts with demographic part to know the respondent more and how related to the study, the second part is the variables questions.

\section{Data Analysis}

The questionnaire was combined of ordinal and likert scales as likert questions were ranked as (Strongly disagree, Disagree, Neither Agree, Strongly Agree). Responses were accepted only from Facebook active users. SPSS program was used in order to analyze the quantitative data, the mean and standard deviation of the answers were extracted. Other types of data analysis such as t-test, regression were used to conclude the result. The study used two statistical techniques which are: Simple Percentage Analysis and Regression Analysis. software for analyzing which was used for this study is IBM SPSS version 23.

\section{INTERPRETATION AND DATA RESULTS}

\section{Reliability Analysis}

Reliability is the method that is done to evaluate the quality of the measurement tools (respondents' answers to the questioner), when doing a research using quantitative study that should be measured indirectly a measurement instrument is common to be used. 
Table 2: Reliability Assessment (Alpha test)

\begin{tabular}{cccc}
\hline Variable name & $\begin{array}{l}\text { Cronbach's } \\
\text { Alpha }\end{array}$ & $\begin{array}{l}\text { Cronbach's Alpha } \\
\text { Standardized Items }\end{array}$ & $\begin{array}{c}\text { Based on N of } \\
\text { Items }\end{array}$ \\
\hline $\begin{array}{c}\text { Perception about } \\
\text { brand Facebook } \\
\text { page }\end{array}$ & .93 & .93 & 9 \\
$\begin{array}{c}\text { Consumer attitude } \\
\text { toward brand } \\
\text { Facebook } \\
\text { advertisement }\end{array}$ & .76 & & \\
\hline
\end{tabular}

According to the results above it can be concluded that the study measurement is reliable to be used for testing the hypothesis.

\section{Independent Sample T-test}

An independent samples t-test compares the means of two groups. It helps to compare the means of two sets of data. For example, the t-test is run to know the average differences of test scores of males and females If the testing P-Value is less than 0.05 there is a difference between the groups. The $\mathrm{P}$ value of the two hypotheses were found as $\mathrm{H}_{1}$ was equal to 0.51 which is higher than 0.5 and the hypothesis was rejected, $\mathrm{H}_{2}$ was equal to 0.14 and no differences were deducted.

\section{Regression Analysis for $\mathrm{H}_{3}$ Testing}

Regression is defined according to Gkioulekas \& Papageorgiou (2019) as "a predictive analysis tool that examines the relationship between independent and dependent variables, to fit a mathematical function describing how the value of the response changes when the values of the predictors vary" (Gkioulekas \& Papageorgiou, 2019)

Linear regression is the simplest form of regression, multiple regression, works on explaining the data by simply fitting a hyperplane minimizing the absolute error of the fitting. Regression Analysis for Hypotheses Testing result is indicated by $\mathrm{P}$ value (Hair Jr, et al., 2014). The Regression Analysis for Hypotheses Testing results is shown in the below tables. 
Table 3: Results

\begin{tabular}{|c|c|c|c|}
\hline & uare $(0.312)$ & \multicolumn{2}{|c|}{ F. Statistics (102.162) } \\
\hline \multicolumn{2}{|c|}{ Adjusted R- Square (0.309) } & \multicolumn{2}{|c|}{ Mean Square (27.886) } \\
\hline \multicolumn{2}{|c|}{ S. E. of Regression (5.281) } & \multicolumn{2}{|c|}{ S.D. Dependent Var. (0.995) } \\
\hline \multicolumn{4}{|c|}{ Sum Square Resid (6274.444) } \\
\hline \multicolumn{4}{|c|}{ Table 4: Coefficients } \\
\hline Model & Unstandardized & $\begin{array}{l}\text { Standard } \\
\text { Error }\end{array}$ & Standardized $t \mathbf{p}$ \\
\hline $\mathrm{H}_{0}$ & $\begin{array}{l}\text { (Intercept) } \\
17.053\end{array}$ & 0.422 & $40.438<.0001$ \\
\hline
\end{tabular}

Table 5: The Regression Analysis for Hypotheses Testing Results

\begin{tabular}{llllll}
\hline \multicolumn{5}{c}{ Coefficients } \\
\hline & $\begin{array}{l}\text { Unstandardized } \\
\text { Coefficients }\end{array}$ & $\begin{array}{l}\text { Standardized } \\
\text { Coefficients }\end{array}$ & \\
\cline { 2 - 5 } Model & $\mathrm{B}$ & Std. Error & Beta & T & Sig. \\
\cline { 1 - 5 } $\begin{array}{l}\text { Perception about brand } \\
\text { Facebook page }\end{array}$ & .359 & .036 & .559 & 10.108 & .000 \\
\hline
\end{tabular}

a. Dependent Variable: Consumer attitude toward brand Facebook advertisement

The P-value which is less than 0.05 results lead to conclude that all the hypotheses are accepted. Consumer attitude toward brand Facebook advertisement $=7.7736+0,359$ (Perception about brand Facebook page.

\section{CONCLUSION}

The findings suggest that perception about brands do not have significant differences regarding gender, based on analysis the finding suggests that the perception about brand page has a significant impact on consumer attitude toward Facebook advertisements. Studies considered gender as a factor of difference regarding perceptions and consumer attitude. In a study done in a study about 
gender differences regarding Facebook privacy, it was found that women are more concerned about their privacy in the Facebook platform than men, the study was applied to Indian people who live in America (Rai, 2011). Perception is the way of viewing the objects although it is a very subjective variable and finding measures are only possible as if it is suggested to be situation-specific or population-directed, perception is not something "objective" (Mcdonald, 2011).

Joining "Online community experience" affect consumer attitude and perception (Nambisan, 2005). Consumer attitude toward technology and the usage of computer differs regarding gender as for most of female participants don't consider it challenging furthermore men were indicating the usage easier than women (Bain \& Rice, 2006: 119). "Consumer's attitude" and "perceived price" are hugely significant factors in buying "private labeled food product" (Jaafar, et al., 2012: 73).

Nowadays people are more affected by brand pages in social media sites, whereas Facebook indicates the likes of friends or the pages they are following. This study claims that perception about brand pages affects consumer attitude toward the content of that page, the importance of creating relevant and right information in social media sites is mentioned. This study contains the significance of brand pages how they affect consumers. To keep or create consumer relationship. Marketers should focus on their brand pages and the advertising timing and methods following their culture and environmental issues. Brand pages should share righteous information regarding their brand and products. The advertising strategies should be created in accordance with the targets' demographic information provided through Facebook. The limitation of this study is related to generalizability because the sample size was small and limited to the youth of Turkey moreover, further aspects of attitude were not considered. Further researches are needed to investigate the aspects of attitude.

\section{REFERENCES}

[1] Archambault, A., Gurdin, J. (2012). A Longitudinal Study of Facebook, LinkedIn, \& Twitter Use. Retrived July 2, $2020 . \quad$ From https://www.microsoft.com/en-us/research/wp-content/uploads/2017/01/ALongitudinal-Study-of-Facebook-LinkedIn-Twitter-Use.pdf.

[2] Asiegbu, I.F., Powei, D.M. and Iruka, C.H. (2012). Consumer attitude: Some reflections on its concept, trilogy, relationship with consumer behavior, and marketing implications. European Journal of Business and Management, 4(13), pp.38-50. 
[3] Atanasova, A. (2016). Gender-specific behaviors on social media and what they mean for online communications. Social Media Today. Retrived July 10, 2020. From https://www.socialmediatoday.com/socialnetworks/gender-specific-behaviors-social-media-and-what-they-meanonline-communications\#: : :text=Social\%20medi

[4] Bain, C.D. and Rice, M.L. (2006). The influence of gender on attitudes, perceptions, and uses of technology. Journal of Research on Technology in Education, 39(2), pp.119-132.

[5] Barreto, A., M. (2013). Does brands' participation on Facebook affect positively brand equity. Doctoral Dissertation.

[6] Barrett, J. (2020). Why Brand Perception Matters and How You Can Measure It. Getfeedback. Retrived August 20, 2020. From https://www.getfeedback.com/resources/cx/brand-perception/

[7] Chen, J. (2020 Jan 24). 5 Actionable strategies for social media branding. Sprout Social. Retrieved Jan 12, 2020. From https://www.quora.com/Whatis-the-difference-between-Instagram-and-Facebook

[8] Coleman, M. (2019). Brand Perception: What It Is, Why it matters and how to measure It. Retrieved August 6, 2020. From https://www.adtaxi.com/blog-roll/2019/2/12/brand-perception-what-it-iswhy-it-matters-and-how-to-measure-it?format=amp

[9] Dutot, V. and Mosconi, E. (2016). Social media and business intelligence: defining and understanding social media intelligence. J. Decis. Syst., 25(3), pp.191-192.

[10] D Souza, W. (2008). Strategies of attitude change. Consumer behavior. $\begin{array}{llll}\text { Retrived Dec } & 20 . & 2020 . & \text { From }\end{array}$ http://consumerbehaviour4vtu.blogspot.com/2008/09/strategies-of-attitudechange.html

[11] Ferreira, F. and Barbosa, B. (2017). Consumers' attitude toward Facebook advertising. International Journal of Electronic Marketing and Retailing, 8(1), pp.45-57.

[12] Frey, C. (2016, Nov 13). How to use content marketing to enhance brand perception. Retrieved August 13, 2020. From. https://contentmarketinginstitute.com/2016/11/content-marketing-brandperception/ 
[13] Gkioulekas, I. and Papageorgiou, L.G. (2019). Piecewise regression analysis through information criteria using mathematical programming. Expert Systems with Applications, 121, pp.362-372.

[14] Gülpınar Demirci, V. and Kaplan, B. (2020). Veri Madenciliği ve Pazarlama, In Dijital Pazarlama Güncel Konular (Eds. C. Soylemez and A. Kayabaş1), Ekin Kitabevi Yayınları, pp. 253-288.

[15] Haron, S.A. (2015). Gender difference in consumer attitude towards purchasing made in Malaysia products. Asian Journal of Social Sciences \& Humanities Vol, 4, p.4.

[16] Hair Jr, J. F., Black, W. C., Babin, B. J., \& Anderson, R. E. (2014). Multivariate Data Analysis (7th ed.). England: Pearson Education Limited

[17] Helbling, M. (2018). Consumer Brand Perception through Social Media: A study on the Influences of Brand Perception on Generation Y.

[18] Helmond, A. Nieborg, D.B. and van der Vlist, F.N. (2019). Facebook's evolution: development of a platform-as-infrastructure. Internet Histories, 3(2), pp.123-146.

[19] Iedunote. (2017). 3 Components of attitude. Retrieved Jan 23, 2020 From. https://www.iedunote.com/components-of-attitudes

[20] Jaafar, S.N., Lalp, P.E. and Naba, M.M. (2012). Consumers' perceptions, attitudes and purchase intention towards private label food products in Malaysia. Asian Journal of Business and Management Sciences, 2(8), pp.73-90.

[21] Kakri, A. (2019). Understanding the ABC model of attitude and live more intelligent. Retrive July 12, 2020. From https://nimblefoundation.wordpress.com/2019/05/03/understand-abcmodel-of-attitude-and-live-more-intelligently/

[22] Kaplan, B. (2015). Marketing Strategies For The Generation "C" Consumer Behavior: An Overview For The GSM Market in Turkey. In Handbook of Research on Developing Sustainable Value in Economics, Finance, and Marketing (pp. 463-475). IGI Global.

[23] Kwon, E. S. (2005). Exploring consumer's attitudes and behavior toward product placement in television shows. Southern Illinois University at Carbondale 
[24] Long-Crowell, N. (2020). How do I change consumer attitudes?. Retrieved Jan 23, 2020 https://smallbusiness.chron.com/change-consumerattitudes-3352.html

[25] Madichie, N. O. (2012). Consumer attitude. Retrieved Feb 5, 2020. From file://C:/Users/USER\%201/Downloads/CB-TC_04\%20(1).pdf

[26] Madsen, D.Ø. and Slåtten, K. (2015). Social media and management fashions. Cogent Business \& Management, 2(1), p.1122256.

[27] Mcdonald, S. M. (2011). Perception: Concept of analysis. Doctoral dissertation University of Texas at Tyler.

[28] Nambisan, P. (2005). Online community experience: impact on customer attitudes. (Master Thesis Rensselaer Polytechnic Institute Troy, New York) Also Available on Proquest UMI Number: 3201894.

[29] Nauert, R. (2012). Gender Influences Perception of Objects. Retrieved June 5, 2020https://psychcentral.com/news/2012/09/18/gender-influencesperception-of-objects/44760.html

[30] Noel, J. (2020). Affective component of attitude: Definition \& Overview. Study.com. Retrieved June 12, 2020. From https://study.com/academy/lesson/affective-component-of-attitudedefinition-lesson-quiz.html

[31] Olsenki, S. (2012). Are Brands Wielding More Influence In Social Media Than WeThought?. Retrieved June 10, 2020. From https:/www.forbes.com/sites/marketshare/2012/05/07/are-brandswielding-more-influence-in-social-media-than-we-thought/\#20b7a7a771e1

[32] Picken, J. (2005). Attitudes and Perceptions. Retreived June 20, 2020 From file://C:/Users/Lenovo/Downloads/Attitudes_and_Perceptions\%20(1).pdf

[33] Patterson, J. (2017). Female perception VS. male perception. Retrieved June 5, 2020 https://www.everydayhealth.com/healthy-living/femaleperception-vs-male-perception/

[34] Rai, P. (2011). Gender Difference in Privacy and Perception about Facebook Advertising: Urban Youth in India and Indian Youth Living In United States of America (Doctoral dissertation, Hawaii Pacific University). 
[35] Ramle, O. and Kaplan, B. (2019). The Power of Instagram Brand Communities: An Overview About Cosmetic Brands On Instagram. Florya Chronicles of Political Economy, 5(1), pp.1-14.

[36] Romaniuk, J., Sharp, B. (2002). Measuring brand perceptions: Testing quantity and quality. Journal of Targeting, Measurement and Analysis for Marketing, 11 (3), 218-229

[37] Sehl, K. (2020). 9 of the most important Facebook trends to watch right now. Hootsuite. Retrieved June 20, 2020. From https://blog.hootsuite.com/facebook-

trends/https://www.singlegrain.com/facebook/facebook-ads-trends-2020/

[38] Siu. E. (2020). 5 Facebook Ads Trends You Can't Ignore in 2020. Single grain. Retrieved June 10, 2020. Fromhttps://www.singlegrain.com/facebook/facebook-ads-trends-2020/.

[39] Smith, K. (2015). The Importance of Brand Perception. Retrieved August 1, 2020https://www.brandwatch.com/blog/marketing-theimportance-of-brand-perception/

[40] Tauber, S. (2014). Perception VS Atttitude- What is the difference. Retrieved July 6, 2020. http://sarahtauber.com/interestingwords/perception-vs-attitude-difference/

[41] Tuskej, M. (2010). Brand perception study. Retrieved August 13, 2020. From.file://C:/Users/Lenovo/Downloads/BPS_MM_creativ.pdf

[42] Vermeren, I. (2015). Men Vs. Women: Who is more active on social media. Brandwatch. Retrived July 9. 2020. From https://www.brandwatch.com/blog/men-vs-women-active-social-media/

[43] Webb, L.M. and Temple, N. (2015). Social media and gender issues. In book: Handbook of Research on the Societal Impact of Digital Media, 638669. doi: DOI: 10.4018. ch025.

[44] Weisberg, J., Te`eni, Dov, Arman, L. (2011). Past purchase and intention to purchase in e-commerce: The mediation of social presence and trust. Journal of Internet research, 21 (1), 82-96

[45] Welbers, K \& Opgenhaffen, O. (2019) Presenting News on SocialMedia. Journal of Digital Journalism, 7:1, 45-62 
[46] WR, J. W. (2015). Perceived Factors Influencing Consumer Trust and Its Impact on Online Purchase Intention in Indonesia. Journal of Science and Research, 6(8).

[47] Ye, L., Robertson, T. M. A. (2012). Gender Identity: Does It Matter for Consumers' Perceptions? Journal of Business Diversity, 12(3), 81-92

[48] Yoon, B., Chung, Y. (2017). Consumer attitude and visit intention toward Food-trucks: targeting Millennials. Journal of Foodservice business research. 21(2), 187-199.

[49] Zhang, X. (2013). Facebook Users' Experience and Attitude Toward Facebook Ads (Doctoral dissertation, Oklahoma State University).

[50] Zhou, Z. (2002). 'Users' attitudes toward web advertising: effects of internet motivation and Internet ability', Advances in Consumer Research. 29(1), 71-78. 